\title{
Phytohormone-Mediated Stomatal Response, Escape and Quiescence Strategies in Plants under Flooding Stress
}

\author{
Kazi Khayrul Bashar ${ }^{1, *(1)}$, Md. Zablul Tareq ${ }^{2}$, Md. Ruhul Amin ${ }^{1}\left({ }^{\circledR}\right.$, Ummay Honi $^{1}{ }^{1}$, \\ Md. Tahjib-Ul-Arif ${ }^{3}{ }^{(D)}$, Md. Abu Sadat ${ }^{1}\left(\mathbb{D}\right.$ and Quazi Md. Mosaddeque Hossen ${ }^{1}{ }^{1}$ \\ 1 Bangladesh Jute Research Institute, Manik Mia Avenue, Dhaka 1207, Bangladesh; \\ shironbge03@gmail.com (M.R.A.); lethe_0000@yahoo.com (U.H.); sadat@snu.ac.kr (M.A.S.); \\ mosaddequebjri@gmail.com (Q.M.M.H.) \\ 2 Bangladesh Jute Research Institute, Jagir, Manikganj 1800, Bangladesh; zablulbarj@gmail.com \\ 3 Department of Biochemistry and Molecular Biology, Bangladesh Agricultural University, Mymensingh 2202, \\ Bangladesh; arif1002215@gmail.com \\ * Correspondence: kazi.khayrulbashar@gmail.com
}

Received: 8 January 2019; Accepted: 16 January 2019; Published: 22 January 2019

\begin{abstract}
Generally, flooding causes waterlogging or submergence stress which is considered as one of the most important abiotic factors that severely hinders plant growth and development. Plants might not complete their life cycle even in short duration of flooding. As biologically intelligent organisms, plants always try to resist or survive under such adverse circumstances by adapting a wide array of mechanisms including hormonal homeostasis. Under this mechanism, plants try to adapt through diverse morphological, physiological and molecular changes, including the closing of stomata, elongating of petioles, hollow stems or internodes, or maintaining minimum physiological activity to store energy to combat post-flooding stress and to continue normal growth and development. Mainly, ethylene, gibberellins (GA) and abscisic acid (ABA) are directly and/or indirectly involved in hormonal homeostasis mechanisms. Responses of specific genes or transcription factors or reactive oxygen species (ROS) maintain the equilibrium between stomatal opening and closing, which is one of the fastest responses in plants when encountering flooding stress conditions. In this review paper, the sequential steps of some of the hormone-dependent survival mechanisms of plants under flooding stress conditions have been critically discussed.
\end{abstract}

Keywords: flood; plants; hormonal homeostasis; physiological activity

\section{Introduction}

Several oxygen limiting factors, such as flooding, waterlogging, and partial or full submergence are detrimental for normal growth and development of plants [1]. Sea, river belt and low land areas experience limited or reduced crop production due to the flooding stress. Plants try to adapt to these adverse conditions by applying several strategies, like the storage of energy, elongation of the petiole or internodes, maintenance of water level by regulating stomatal movements, the formation of adventitious roots, development of aerenchyma etc. [2-5]. Crop plants simultaneously activate various biochemical reactions, molecular and signaling pathways, and physiological processes to cope with this oxygen-limiting condition $[1,6]$.

Phytohormone plays a central role in all morphological, anatomical, biochemical, molecular and signaling mechanisms for plant survival under oxygen-limiting stress conditions. Predominantly, ethylene, gibberellins (GA) and abscisic acid (ABA) play the most crucial roles during submergence stress conditions in plants [7]. Ethylene directly and/or indirectly induces GA expression that aids 
plants in carrying out the escape and/or quiescence strategy. Petiole/internode elongation and storage of carbohydrates results from the escape and quiescence strategy, respectively in plants under submergence stress [8]. GAs are directly involved in escaping submergence stress in both DELLA (N-terminal D-E-L-L-A amino acid sequence) dependent and independent pathways [9]. Furthermore, ethylene and $\mathrm{ABA}$ are directly responsible for the stomatal closure under waterlogging or post-waterlogging stress [10]. On the other hand, GAs are responsible for the stomatal opening under the same stress conditions [11]. So, balanced expression of these three hormones is highly indispensable to maintain the ratio of stomatal opening and closing in plants under excess water stress conditions.

Based on the above facts, this review paper proposes flowcharts of sequential steps for stomatal closing and escaping and quiescencing strategies to offer the best possible explanations. This might help plant scientists to consider several factors during the development of waterlogging-tolerant plant varieties.

\section{Ethylene, GA and ABA Interactions in Plants under Submergence Stress}

Under submergence stress, ethylene, GA and ABA play influential roles in the survivability of the submerged plants, where ABA biosynthesis is reduced and GA signaling is induced for shoot elongation, especially in rice plants (variety: C9285) [12,13].

Plants have evolved two types of strategies, i.e., escape strategy and quiescence strategy, to survive under flooding stress. In the escape strategy, the rice plant elongates its internodes under slow progressive flooding conditions. On the other hand, rice plants reserve energy under deep transient flash flooding conditions to escape the unfavorable conditions, which is termed the quiescence strategy [14,15]. It is quite interesting that two different functions of two distinct gene families under the same subgroup of a transcription factor are involved in submergence tolerance in plants. This is a complex process, but one that is interesting to study, and required to unveil this mechanism by functional genomics. Under the AP2/ERF (Apelata2/Ethylene response factor) transcription factor (TF) subgroup, the Snorkel (SK) gene is responsible for internode elongation, whereas Sub1A (Submergence 1A) is related to shoot elongation restriction [16].

In low land rice varieties, the ERF transcription factor, Sub1, is considered as a major player in submergence tolerance $[17,18]$. As a quiescence strategy in rice genotypes, ethylene directly enhances Sub1A expression. Sub1A induces the over accumulation of GA signaling repressors, Slender Rice-1 (SLR1) and SLR1 Like-1 (SLRL1). Sub1A, a group under VII AP2/ERF transcription factor, restricts shoot elongation by suppressing the SLR1 and SLRL2 for saving energy that is necessary for growth and development under desubmergence conditions. Therefore, ethylene is indirectly responsible for the induction of these GA signaling repressors and the reduction of GA responsive gene expression under submergence stress through the Sub1A-dependent pathway. Sub1A may also play an important role in limiting ethylene production during submergence stress conditions, resulting in the restriction of ethylene-induced enhancement of GA responsiveness in submergence tolerant varieties [17]. The function of Sub1A1 is also regulated by MPK3 (Mitogen-activated protein kinase3). MPK3-dependent phosphorylated Sub1A1 binds to the G-box of the MPK3 promoter to regulate its activity [19].

On the other hand, ethylene can directly enhance GA responsive shoot elongation in rice genotypes as an escape strategy of submergence stress, which is not only a highly energy-consuming process, but also requires the continuous production of energy. Due to the lack of Sub1A in submergence-susceptible genotypes, plants' survivability in the desubmergence stage is very low or limited [20]. Thus, Sub1A acts as a limiting factor for ethylene-promoted GA responsive shoot elongation in tolerant genotypes during submergence conditions to store or save the energy required for normal physiological and biochemical activities [21].

Moreover, in rice, Sub1A actively participates in maintaining chlorophyll contents and carbohydrate reserves in photosynthetic tissues [22]. Sub1A increases brassinosteroid (BR) levels 
in rice plants under submergence stress. BR induces GA catabolic SLR1 proteins which restrict shoot elongation under oxygen-limiting conditions. In addition, BR enhances the expression of GA2ox7 (GA 2 oxidase 7 ) as an early response (within $1 \mathrm{~d}$ after submergence), which is responsible for catabolic GA degradation of endogenous $\mathrm{GA}_{4}$ [23] (Figure 1). OsAP2-39, an Apelata 2 (AP2) transcription factor, directly regulates the ABA biosynthetic gene OsNCED1 (9-cis-epoxycarotenoid dioxygenase 1) and the GA repressing EUI (Elongation of uppermost internode I) gene. Over-expression of OsAP2-39 has been shown to enhance drought resistance in rice by producing more ABA and degrading GA [24], which supports the antagonistic crosstalk between ABA and GA as a crucial mechanism to control plant growth and development under abiotic stress conditions [25]. From the above discussion, it can be said that OsAP2-39 might have great scope to restrict GA signaling in plants under waterlogging or submergence conditions, and stomatal control through ABA signaling pathways under desubmergence conditions.

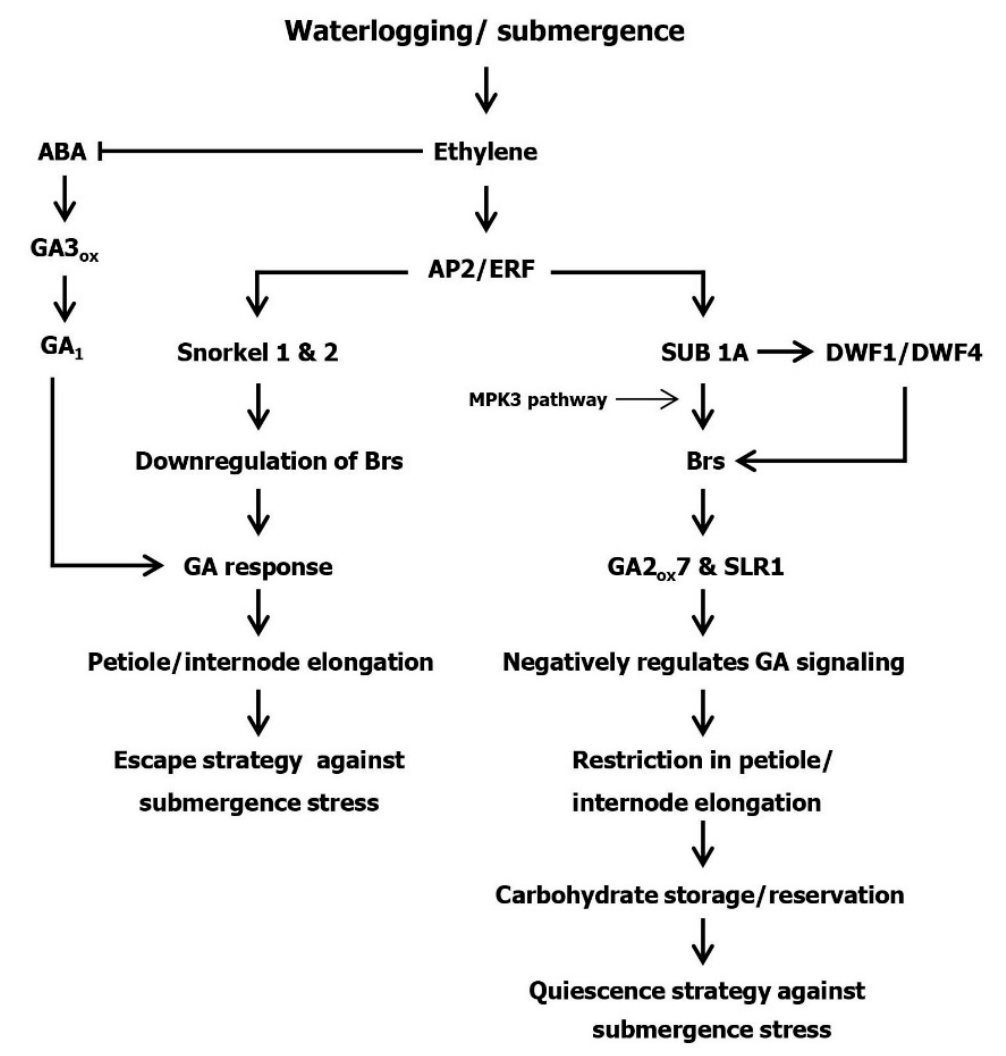

Figure 1. Ethylene-mediated escape and quiescence strategies in plants against submergence stress. Enhanced ethylene expression under submergence stress induces Snorkel and Sub1A genes for escape and quiescence strategies respectively. Ethylene suppresses ABA expression, which triggers $\mathrm{GA}_{1}$ expression for escape strategy in plants. ABA: Abscisic acid; AP2/ERF: Apelata2/Ethylene response factor; Brs: Brassinosteroids; DWF1/4: Dwarf 1/4; GA 1 : Gibberellins 1; GA2ox7: GA 2 oxidase7; GA3ox: GA 3 oxidase; Sub1A: Submergence1A; SLRL1: SLR1 Like-1.

In deep water rice, ethylene enhances the expression of Snorkel1 (SK1) and Snorkel2 (SK2) which are responsible for significant internode elongation via GA signaling pathways [26]. Snorkel genes are only present in lowland deepwater rice accessions for their internode elongation through downregulation of BR biosynthesis as an escape mechanism under submergence stress [1] (Figure 2). 


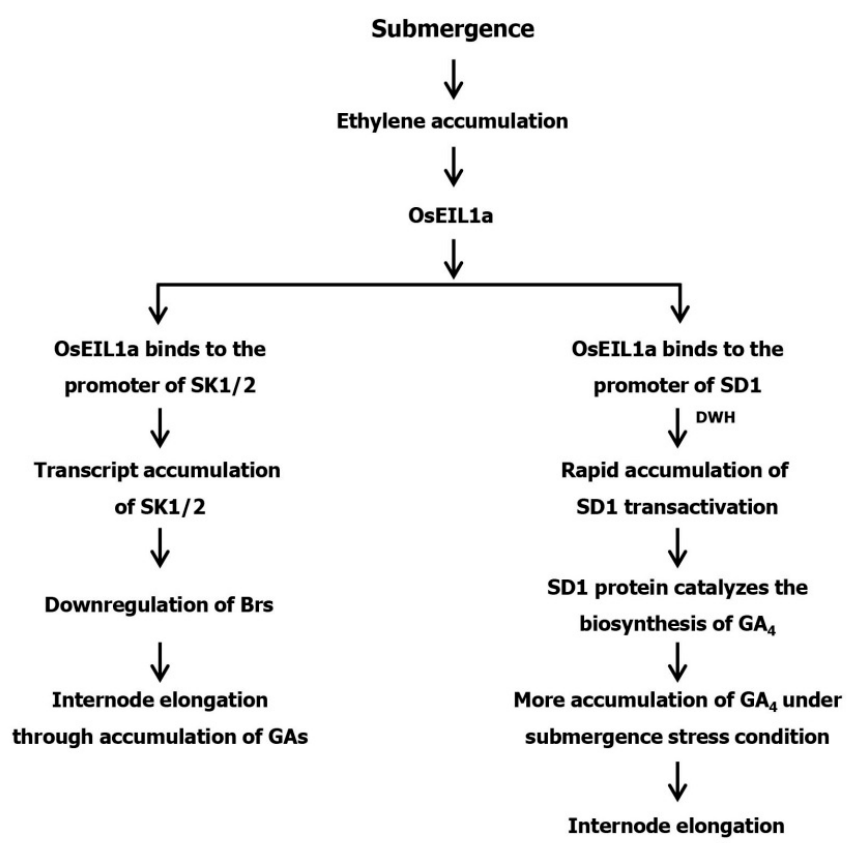

Figure 2. Proposed model for rice internode elongation under submergence stress conditions. Modified figure [13]. EIL1a binds with the both promoters of $S K 1 / 2$ and $S D 1$ in rice under submergence stress conditions. SK1/2 downregulates Brs that induce internode elongation through the accumulation of GAs. On the other hand, SD1 induces internode elongation through the accumulation of $\mathrm{GA}_{4}$. Brs: brassinosteroids; EIL1a: Ethylene Insensitive 3-like 1a; GA: Gibberellins; SD1: Semidwarf1; SK1/2: Snorkel 1/2.

In rice, Snorkel dependent (variety: C9285) and independent (variety: T65) internode elongation for escaping the submergence stress conditions was discovered by [13]. In this escaping strategy the accumulated ethylene enhances OsEIL1a (Ethylene Insensitive 3-like 1a) in rice plants. In the Snorkel dependent escaping strategy, OsEIL1a binds to the promoter of Snorkel1/2 to accumulate the transcript of Snorkel1/2 [27]. This leads to the downregulation of BR to induce GA-mediated (mainly GA $\mathrm{GA}_{1}$ ) internode elongation [22,25]. GA response enhances the expression of cyclins transcription factor, which leads to rapid cell division in lotus (Nelumbo nucifera) under submergence stress conditions [28]. However, as a Snorkel independent escaping strategy, OsEIL1a binds to the promoter of SD1 (Semidwarf1) for DWH (deepwater rice-specific haplotype) mediated rapid amplification of SD1 transactivation. The SD1 protein catalyzes the biosynthesis of bioactive GA species, $\mathrm{GA}_{4}$ that increases $\mathrm{GA}_{4}$ level in addition to $\mathrm{GA}_{1}$ after submergence. $\mathrm{GA}_{4}$ is more capable of internode elongation than $\mathrm{GA}_{1}$ [13]. So, Snorkel independent SD1 mediated internode elongation in rice is comparatively faster than that of the Snorkel dependent pathway (Figure 2).

Rumex plants showed Snorkel independent petiole elongation. In flood-tolerant Rumex palustris, ethylene reduces RpNCED expression which inhibits ABA biosynthesis. Thus, $R$. palustris elongates its petiole by degrading $\mathrm{ABA}$ into phaseic acid and enhancing $\mathrm{GA}_{1}$-mediated gene expression in an ethylene-mediated pathway under oxygen-limited condition [29]. R. palustris maintains gas exchange between the submerged tissues and the atmosphere by elongating shoots under long-term flooding stress condition $[29,30]$. In this stress condition, the accumulation of ethylene not only breaks down ABA into phaseic acid, but also downregulates ABA expression by inhibiting 9-cis-epoxycarotenoid dioxygenase expression. Elevated content of ethylene independently degrades ABA through ABA 8 ' hydroxylase pathway under submergence stress conditions [31]. Inhibition of ABA stimulates GA 3-oxidase to produce bioactive GA $\left(\mathrm{GA}_{1}\right)$. The downstream function of GA is to mobilize food materials by the breakdown of starch and cell wall loosening, which ultimately elongates internode or leaf sheath to escape submergence or waterlogging stress conditions [30]. In rice, a similar type of ABA-dependent GA expression was also reported [32]. Both the quiescence strategy and escape 
strategy are considered as the survival mechanisms of plants under submergence stress, but escape strategy is considered as a yield limiting factor in rice plants under de-submergence stress [33].

\section{DELLA-Dependent GA Expression under Submergence Stress}

Gibberellin-insensitive dwarf 1 (GID1), a soluble receptor for GA signaling, is involved in GA-mediated signaling pathways in plants under stress conditions, especially during abiotic stress conditions [34,35]. GA binds to GID1 and generates a GID1-GA complex which has the ability to interact with different growth repressors like DELLA or SLENDER1 (SLR1), a DELLA ortholog in rice [33]. Five types of DELLA are present in the model plant Arabidopsis thaliana, namely Gibberellin-insensitive (GAI), Repressor of GA1-3 (RGA), RGA-like1 (RGL1), RGL2 and RGL3 [36]. GID1-GA complex facilitates GA-mediated interaction between GID1 and DELLA protein, which is responsible for conformational changes in DELLA proteins. The Sleepy1 (SLY1) gene contain the F-box domain, which is a positive regulator of GA signaling in Arabidopsis. Sleepy1 (SLY1) in Arabidopsis and GID2 in rice are capable of recognizing this change of DELLA proteins where SCF (SLY1) (Skp1, Cullin, F-box), E3 ubiquitin ligase ubiquitinates DELLA protein, targeting DELLA for degradation through proteolysis by the $26 \mathrm{~S}$ proteasome $[34,35,37]$. Thus GA expression is continued in plants by suppressing the expression of DELLA protein (Figure 3A).

3A

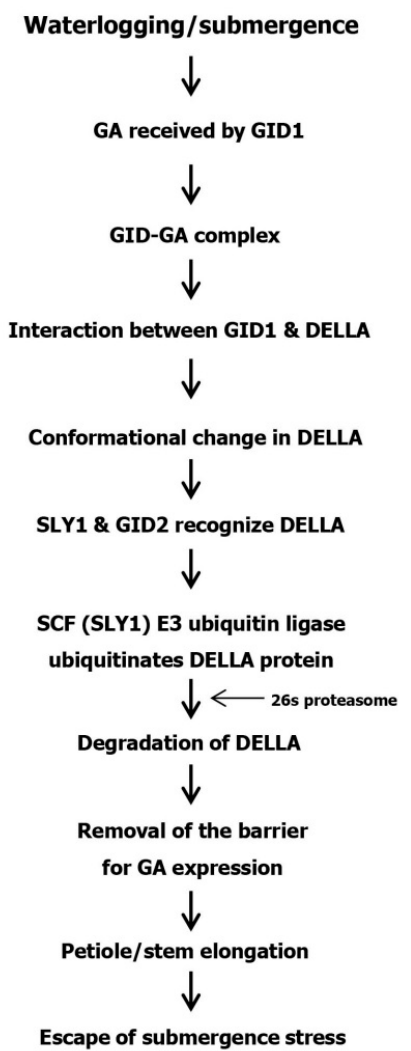

3B

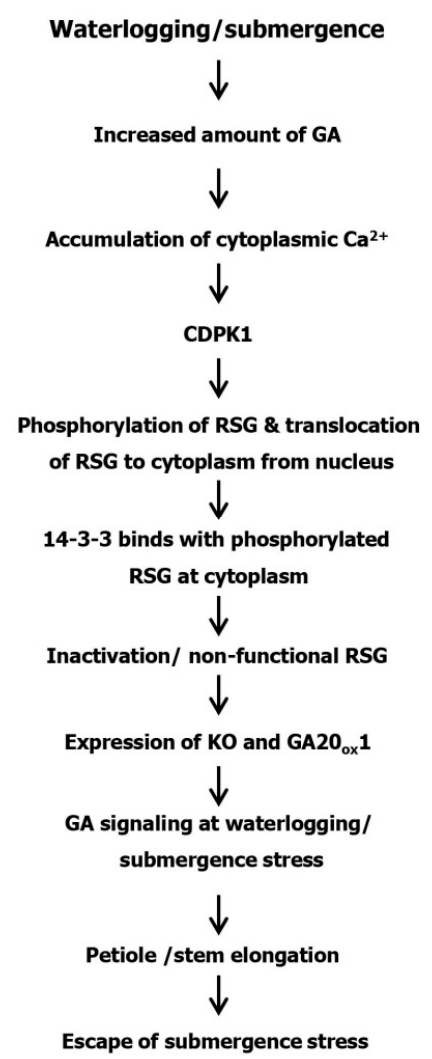

Figure 3. DELLA-dependent and -independent GA signaling in plants under submergence stress conditions. (3A) DELLA-dependent escape strategy in plants; GID-GA complex makes conformational change in DELLA. After that SCF ubiquitinates DELLA protein which induces GA expression for petiole/stem elongation. (3B) DELLA-independent escape strategy in plants; $\mathrm{Ca}^{2+}$ accumulation enhances CDPK1 production for the phosphorylation of RSG to translocate it into the cytoplasm from nucleus. 14-3-3 inactivates RSG as a GA-mediated submergence escaping strategy. CDPK1: Ca2+-dependent protein kinase 1; DELLA: N-terminal D-E-L-L-A amino acid sequence; GA: Gibberellins; GA20ox1: GA 20 oxidase1; GID1: Gibberellin-insensitive dwarf 1; GID2: Gibberellin-insensitive dwarf 2; RSG: Repression of shoot growth; SCF: Skp1, Cullin, F-box; SLY1: Sleepy1. 


\section{DELLA Independent GA Expression under Submergence Stress}

GAs can increase cytoplasmic $\mathrm{Ca}^{2+}$ very rapidly during various cellular processes occurring inside the cell. However, the mechanism of increasing GA-mediated cytoplasmic $\mathrm{Ca}^{2+}$ in a DELLA-independent manner is still unknown. The GA-mediated increase of $\mathrm{Ca}^{2+}$ and degradation of DELLAs are completely independent processes [38]. An elevated level of cytoplasmic $\mathrm{Ca}^{2+}$ activates $\mathrm{Ca}^{2+}$-dependent protein kinase (NtCDPK1) via a DELLA-independent GA pathway in tobacco [39]. $\mathrm{NtCDPK} 1$ is responsible for the translocation of Repression of shoot growth (RSG) from the nucleus to the cytoplasm [40,41]. RSG represses the expression of two important GA biosynthetic genes, $N t K O$ and NtGA20ox1, which are considered as GA enhancing genes [42,43]. RSG binds to the promoter region of NtGA20ox1 through GA-mediated approach while RSG binds to NtKO promoter in the independent manner of GA concentrations [43]. NtCDPK1 acts as a RSG kinase and phosphorylates RSG, which promotes 14-3-3 to bind with RSG at cytoplasm [40,44,45]. In rice plants, CDPK is induced under low oxygen stress for survivability under anaerobic conditions [46]. 14-3-3 proteins directly bind to the RSG in the cytoplasm and regulate RSG function negatively, making non-functional RSG [41,47]. So, inactivation of RSG by 14-3-3 proteins indirectly helps to express both $N t K O$ and NtGA20ox1 to continue GA biosynthesis for different cellular processes (Figure 3B).

\section{ABA in Plants under Waterlogging Stress}

Imbalanced conditions between leaf transpiration and root water uptake creates dehydration (physiological drought) stress in plants, that is noticed in plants under waterlogging stress with partially or fully damaged root tissues. The plant hormone ABA has the ability to modify root hydraulic properties [48]. For example, ABA downregulation and upregulation in tomato plants expresses lower and higher hydraulic conductance, respectively $[49,50]$. Depending on both the flooding duration and plant species, ABA differentially responds in leaves and in the roots of plants. Malus sieversii is considered as less tolerant to hypoxia than Malus hupehensis, showing a larger increase in ABA in both the leaf and root tissues [51]. In Gerbera jamesonii, ABA levels were increased in both leaf and root, where a transient increase in root follows a sharp decrease in the recovery period [52]. ABA is also increased in roots and leaves of Triticum aestivum L., but gradually decreases after reaching certain levels [53].

\section{Stomatal Regulation at Waterlogging Stress}

Stomata is a specialized epidermal pore-like structure consisting of two guard cells through which plants exchange both $\mathrm{CO}_{2}$ and $\mathrm{O}_{2}$ with the environment $[54,55]$. Stomatal conductance was insignificantly affected by flooding stress despite a significant reduction of photosynthesis in both flood-tolerant and flood-sensitive poplar genotypes [56]. A similar finding was also reported in maize plants where flooding resulted in a significant decrease in photosynthesis and ribulose-1,5-bisphosphate carboxylase activity without a noticeable reduction in the rates of stomatal conductance [57]. In GID1 mutated rice plant, increased chlorophyll content has been found, which is subsequently responsible for the increase of carbohydrate production and decrease of reactive oxygen species (ROS) accumulation under submergence stress [58]. Reduction in leaf transpiration is a common phenomenon of flooding stress, which affects the lowered stomatal aperture [59-61]. It is difficult to believe that flooding paradoxically causes leaf dehydration in plants [62-64]. Stomatal closing is operated by the turgor pressure and volume of guard cells. ABA-dependent signaling effluxes of anions, potassium ions and conversion of malate into starch trigger the reduction of turgor pressure, as well as changing the volume of guard cells close the stomata [65]. Under hypoxic stress, hypoxia responsive universal stress protein 1 (HRU1) activates AtrbohD (Respiratory burst oxidase homolog protein D), following interaction between ROP2 (Rho of plants 2) and AtrbohD in Arabidopsis under low oxygen stress conditions. NADPH oxidase AtrbohD is responsible for alcoholic fermentation and ABA-dependent stomatal closure in plants under abundant water conditions [66,67]. It has been 
reported that barley plants swiftly close the stomata after flooding stress imposition [68]. A similar phenomenon was also observed in pea plants under flooding conditions, where a prompt closure of stomata from older leaves was recorded. Wilting of younger leaves was protected by older pea leaves by increasing ABA-dependent stomatal closure [69]. Unwilted younger pea leaves might result from the ABA transportation from older to younger leaves or de novo biosynthesis of ABA in the younger leaves [70]. Though Populus deltoides is considered as a waterlogging tolerant plant species, it showed a significant reduction in stomatal conductance at both waterlogging and de-waterlogging stress, with an exception at recovery period after 90 days of waterlogging stress [71].

\section{Hormonal Regulation in Stomatal Closing of Plants under Waterlogging Stress}

Several waterlogging related experiments showed a positive correlation between ABA accumulation and increase in ROS, in soybean roots [72], barley roots and leaves [73], maize leaves [74], bread wheat roots [75]. The enzymatic mechanisms responsible for ABA-triggered ROS generation in guard cells at the molecular level are little known at present. ABA initiates $\mathrm{H}_{2} \mathrm{O}_{2}$ generation by using the plasma membrane NADPH oxidase [76]. $\mathrm{H}_{2} \mathrm{O}_{2}$ activates plasma membrane $\mathrm{Ca}^{2+}$ channels, resulting in an increase in $\mathrm{Ca}^{2+}$ level in guard cells. [77]. Inhibition of inward $\mathrm{K}^{+}$channels in guard cells is the result of increased $\mathrm{Ca}^{2+}$ level in the cytoplasm of guard cells [78,79]. This results in reduced solute accumulation following a reduced amount of water entrance in the guard cells and ultimately leading to stomata closure [80]. In Arabidopsis, $\mathrm{H}_{2} \mathrm{O}_{2}$ can also stimulate $\mathrm{NO}$ (nitric oxide) production to induce stomatal closure [81]. Ethylene and ABA activate CuAO (copper amine oxidase) in Vicia faba [82,83]. Oxidation of putrescine by $\mathrm{CuAO}$ produces $\mathrm{H}_{2} \mathrm{O}_{2}$, follows stomatal closure in $V$. faba [82] (Figure 4). ABA is also responsible for stomatal closing in plants as a survival mechanism under post-waterlogging stress [84].

Moreover, $\mathrm{H}_{2} \mathrm{O}_{2}$ is also produced by extracellular calmodulin (ExtCaM) which is activated by heterotrophic $G$ protein [85]. In rice, accumulated ethylene induces $G$ protein for aerenchyma formation under flooding stress [86]. $\mathrm{G}$ protein induces $\mathrm{H}_{2} \mathrm{O}_{2}$ production for epidermal cell death in rice under submergence stress [87]. Inactivation of CTR1 (Constitutive triple response 1) is induced by the binding of ethylene to ETR1 (Ethylene receptor 1), ERS1 (Ethylene response sensor 1) and EIN4 (Ethylene insensitive 4), resulting in the activation of $\mathrm{G}_{\text {alpha }}$ ( $\mathrm{G}$ protein alpha subunit). $\mathrm{G}_{\text {alpha }}$ promotes $\mathrm{H}_{2} \mathrm{O}_{2}$ production in plants via NADPH oxidases. ETR1 and ERS1 translocate the signals of $\mathrm{H}_{2} \mathrm{O}_{2}$ to EIN2, EIN3 and ARR2 (2-component response regulator), which are essential for stomatal closure functioning [88]. Activated $\mathrm{G}$ proteins may inhibit inward $\mathrm{K}^{+}$channels via an elevated level of cytoplasmic $\mathrm{Ca}^{2+}$ in the guard cells $[78,79]$. From the above discussion, a proposed signaling pathway may work for stomatal closure in plants under waterlogging stress (Figure 4).

In Arabidopsis thaliana, flooding stress operates $\mathrm{H}_{2} \mathrm{O}_{2}$-mediated stomatal closure followed by an increase in antioxidant enzyme activities [89]. Improvement of anoxia tolerance was confirmed by applying exogenous ABA in different plants including maize, citrus, lettuce and Arabidopsis [90-94]. Waterlogged pea plant restricted its leaf ABA to translocate in shoot, while in non-waterlogged plants, ABA moves readily from shoots to roots $[95,96]$. This extra ABA in pea leaves was responsible for reducing leaf transpiration by the closing of stomata [96].

Stomata closing may occur in an ABA-independent manner. As for example, ABA was increased in citrus after 3 weeks of flooding, indicating that closing of stomata and increase of ABA are independent in citrus plants upon flooding stress, and not only that ABA was transported to younger leaves from older leaves, rather than, as expected, being transportated from roots to shoots [97]. 


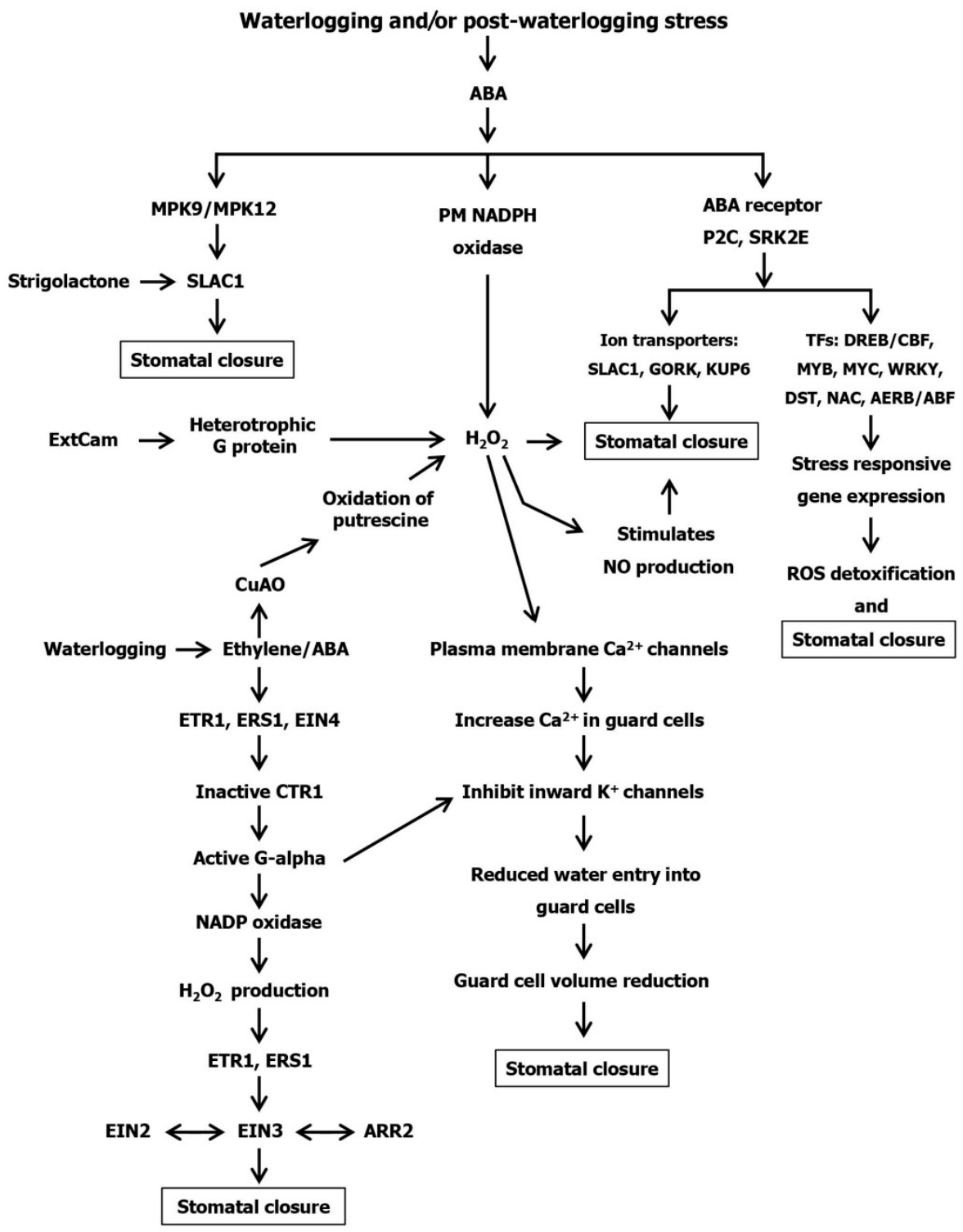

Figure 4. Proposed model for hormone mediated stomatal closure under waterlogging and/or post-waterlogging stress conditions. Modified figure [84]. Ethylene and/or ABA are directly or indirectly enhance $\mathrm{H}_{2} \mathrm{O}_{2}$ production under waterlogging and/or post-waterlogging stress conditions. $\mathrm{H}_{2} \mathrm{O}_{2}$ is directly responsible for closing of stomata or indirectly increasing $\mathrm{Ca}^{2+}$ in the guard cell for stomatal closure by reducing the volume of the guard cell. ABA: Abscisic acid; AREB/ABF: (ABA)-responsive element binding proteins/ABRE(ABA-responsive element)-binding factors; ARR2: 2-component response regulator; CTR1: Constitutive triple response 1; CuAO: Copper amine oxisase; DREB/CBF: Dehydration-responsive element-binding/C-repeat binding factor; DST: Drought and salt tolerance; EIN: Ethylene Insensitive; ERS1: Ethylene response sensor 1; ETR1: Ethylene receptor 1; ExtCaM: Extracellular Calmodulin; GORK: Guard cell outward-rectifying K+; KUP6: K+ uptake transporter 6; MPK3/9: Mitogen-activated protein kinase3/9; MYB: Myeloblastosis; MYC2: Myelocytomatosis; NAC: NAM (No apical meristem), ATAF (Arabidopsis transcription activation factor) and CUC (Cup-shaped cotyledon) transcription factor; P2C: Protein phosphatase 2C; ROS: Reactive oxygen species; SLAC1: Slow anion channel-associated 1; SRK2E: SNF1 (Sucrose nonfermenting 1)-related protein kinase 2; WRKY: W-tryptophan, R-arginine, K-lysine, Y-tyrosine. 


\section{Conclusions}

From this above discussion, it can be concluded that ethylene directly or indirectly regulates the expression of gibberellins (GAs) and abscisic acid (ABA) in plants under flooding stress conditions. However, ABA plays a major role in stomatal closing, whereas escape and quiescence strategies are controlled by the expression of GA. Finally, it can be concluded that plants maintain their internal homeostasis by balancing hormonal cross talk under excess water stress.

Author Contributions: Conceptualization and writing-original draft preparation, K.K.B.; Writing-review and editing, K.K.B.; M.Z.T, M.R.A., U.H. and M.T.-U.-A.; Supervision, M.A.S. and Q.M.M.H.

Funding: This research received no external funding.

Conflicts of Interest: The authors declare no conflict of interest.

\section{References}

1. Tamang, B.G.; Fukao, T. Plant adaptation to multiple stresses during submergence and following desubmergence. Int. J. Mol. Sci. 2015, 16, 30164-30180. [CrossRef] [PubMed]

2. Bailey-Serres, J.; Fukao, T.; Ronald, P.; Ismail, A.; Heuer, S.; Mackill, D. Submergence tolerant rice: SUB1's journey from landrace to modern cultivar. Rice 2010, 3, 138-147. [CrossRef]

3. Verboven, P.; Pedersen, O.; Quang, T.H.; Nicolai, B.M.; Colmer, T.D. The mechanism of improved aeration due to gas films on leaves of submerged rice. Plant Cell Environ. 2014, 37, 2433-2452. [CrossRef] [PubMed]

4. Eysholdt-Derzsó, E.; Sauter, M. Hypoxia and the group VII ethylene response transcription factor HRE2 promote adventitious root elongation in Arabidopsis. Plant biol. 2018, 1, 103-108. [CrossRef] [PubMed]

5. Yamauchi, T.; Colmer, T.D.; Pedersen, O.; Nakazono, M. Regulation of root traits for internal aeration and tolerance to soil waterlogging-flooding Stress. Plant Physiol. 2018, 176, 1118-1130. [CrossRef]

6. Lin, I.; Wu, Y.; Chen, C.; Chen, G.; Hwang, S.; Jauh, G.; Tzen, J.T.C.; Yang, C. AtRBOH I confers submergence tolerance and is involved in auxin-mediated signaling pathways under hypoxic stress. Plant Growth Regul. 2017, 83, 277-285. [CrossRef]

7. Phukan, U.J.; Mishra, S.; Shukla, R.K. Waterlogging and submergence stress: Affects and acclimation. Crit. Rev. Biotechnol. 2015, 36, 956-966. [CrossRef] [PubMed]

8. Xiang, J.; Wu, H.; Zhang, Y.; Zhang, Y.; Wang, Y.; Li, Z.; Lin, H.; Chen, H.; Zhang, J.; Zhu, D. Transcriptomic analysis of gibberellin- and paclobutrazol-treated rice seedlings under submergence. Int. J. Mol. Sci. 2017, 18, 2225. [CrossRef]

9. Colebrook, E.H.; Thomas, S.G.; Phillips, A.L.; Hedden, P. The role of gibberellin signaling in plant responses to abiotic stress. J. Exp. Biol. 2014, 217, 67-75. [CrossRef] [PubMed]

10. Else, M.A.; Janowiak, F.; Atkinson, C.J.; Jackson, M.B. Root signals and stomatal closure in relation to photosynthesis, chlorophyll a fluorescence and adventitious rooting of flooded tomato plants. Ann. Bot. 2009, 103, 313-323. [CrossRef]

11. Göring, H.; Koshuchowa, S.; Deckert, C. Influence of gibberellic acid on stomatal movement. Biochem. Physiol. Pflanzen 1990, 186, 367-374. [CrossRef]

12. Bailey-Serres, J.; Voesenek, L.A.C.J. Life in the balance: A signaling network controlling survival of flooding. Curr. Opin. Plant Biol. 2010, 13, 489-494. [CrossRef] [PubMed]

13. Kuroha, T.; Nagai, K.; Gamuyao, R.; Wang, D.R.; Furuta, T.; Nakamori, M.; Kitaoka, T.; Adach, K.; Minami, A.; Mori, Y.; et al. Ethylene-gibberellin signaling underlies adaptation of rice to periodic flooding. Science 2018, 361, 181-186. [CrossRef] [PubMed]

14. Bailey-Serres, J.; Fukao, T.; Gibbs, D.J.; Holdsworth, M.J.; Lee, S.C.; Licausi, F.; Perata, P.; Voesenek, L.A.C.J;; Dongen, J.T.V. Making sense of low oxygen sensing. Trends Plant Sci. 2012, 17, 129-138. [CrossRef] [PubMed]

15. Fukao, T.; Xiong, L. Genetic mechanisms conferring adaptation to submergence and drought in rice: Simple or complex? Curr. Opin. Plant Biol. 2013, 16, 196-204. [CrossRef] [PubMed]

16. Jung, K.; Seo, Y.; Walia, H.; Cao, P.; Fukao, T.; Canlas, P.E.; Amonpant, F.; Bailey-Serres, J.; Ronald, P.C. The submergence tolerance regulator Sub1A mediates stress-responsive expression of AP2/ERF transcription factors. Plant Physiol. 2010, 152, 1674-1692. [CrossRef] [PubMed] 
17. Fukao, T.; Xu, K.; Ronald, P.C.; Bailey-Serres, J. A variable cluster of ethylene response factor-like genes regulates metabolic and developmental acclimation responses to submergence in rice. Plant Cell 2006, 18, 2021-2034. [CrossRef] [PubMed]

18. Xu, K.; Xu, X.; Fukao, T.; Canlas, P.; Maghirang-Rodriguez, R.; Heuer, S.; Ismail, A.M.; Bailey-Serres, J.; Ronald, P.C.; Mackill, D.J. Sub1A is an ethylene-response-factor-like gene that confers submergence tolerance to rice. Nature 2006, 442, 705-708. [CrossRef] [PubMed]

19. Singh, P.; Sinha, A.K. A positive feedback loop governed by SUB1A1 interaction with Mitogen-activated protein kinase3 imparts submergence tolerance in rice. Plant Cell. 2016, 28, 1127-1143. [CrossRef] [PubMed]

20. Locke, A.M.; Gregory, A.B., Jr.; Sathnur, S.; Larive, C.K.; Bailey-Serres, J. Rice SUB1A constrains remodeling of the transcriptome and metabolome during submergence to facilitate post-submergence recovery. Plant Cell Environ. 2018, 41, 721-736. [CrossRef] [PubMed]

21. Fukao, T.; Bailey-Serres, J. Submergence tolerance conferred by Sub1A is mediated by SLR1 and SLRL1 restriction of gibberellin responses in rice. PNAS 2008, 105, 16814-16819. [CrossRef] [PubMed]

22. Fukao, T.; Yeung, E.; Bailey-Serres, J. The submergence tolerance gene SUB1A delays leaf senescence under prolonged darkness through hormonal regulation in rice. Plant Physiol. 2012, 160, 1795-1807. [CrossRef] [PubMed]

23. Schmitz, A.J.; Folsom, J.J.; Jikamaru, Y.; Ronald, P.; Walia, H. SUB1A-mediated submergence tolerance response in rice involves differential regulation of the brassinosteroid pathway. New Phytol. 2013, 198, 1060-1070. [CrossRef] [PubMed]

24. Yaish, M.W.; El-kereamy, A.; Zhu, T.; Beatty, P.H.; Good, A.G.; Bi, Y.; Rothstein, S.J. The APETALA-2-Like transcription factor OsAP2-39 controls key interactions between abscisic acid and gibberellin in rice. PLoS Genet. 2010, 6, e1001098. [CrossRef] [PubMed]

25. Seo, M.; Hanada, A.; Kuwahara, A.; Endo, A.; Okamoto, M.; Yamauchi, Y.; North, H.; Marion-Poll, A.; Sun, T.; Koshiba, T.; et al. Regulation of hormone metabolism in Arabidopsis seeds: Phytochrome regulation of abscisic acid metabolism and abscisic acid regulation of gibberellin metabolism. Plant J. 2006, 48, 354-366. [CrossRef] [PubMed]

26. Hattori, Y.; Nagai, K.; Furukawa, S.; Song, X.; Kawano, R.; Sakakibara, H.; Wu, J.; Matsumoto, T.; Yoshimura, A.; Kitano, H.; et al. The ethylene response factors SNORKEL1 and SNORKEL2 allow rice to adapt to deep water. Nature 2009, 460, 1026-1030. [CrossRef] [PubMed]

27. Voesenek, L.A.; Bailey-Serres, J. Flood adaptive traits and processes: An overview. New Phytol. 2015, 206, 57-73. [CrossRef] [PubMed]

28. Wang, B.; Jin, Q.; Zhang, X.; Mattson, N.S.; Ren, H.; Cao, J.; Wang, Y.; Yao, D.; Xu, Y. Genome-wide transcriptional analysis of submerged lotus reveals cooperative regulation and gene responses. Sci. Rep. 2018, 8, 918. [CrossRef]

29. Benschop, J.J.; Jackson, M.B.; Guhl, K.; Vreeburg, R.A.M.; Croker, S.J.; Peeters, A.J.; Voesenek, L.A.C.J. Contrasting interactions between ethylene and abscisic acid in Rumex species differing in submergence tolerance. Plant J. 2005, 44, 756-768. [CrossRef]

30. Benschop, J.J.; Bou, J.; Peeters, A.J.; Wagemaker, N.; Gühl, K.; Ward, D.; Hedden, P.; Moritz, T.; Voesenek, L.A.C.J. Long-term submergence-induced elongation in Rumex palustris requires abscisic acid-dependent biosynthesis of gibberellin. Plant Physiol. 2006, 141, 1644-1652. [CrossRef]

31. Saika, H.; Okamoto, M.; Miyoshi, K.; Kushiro, T.; Shinoda, S.; Jikumaru, Y.; Fujimoto, M.; Arikawa, T.; Takahashi, H.; Ando, M.; et al. Ethylene promotes submergence-induced expression of OsABA8ox1, a gene that encodes ABA 8-hydroxylase in rice. Plant Cell Physiol. 2007, 48, 287-298. [CrossRef] [PubMed]

32. Bailey-Serres, J.; Voesenek, L.A.C.J. Flooding stress: Acclimations and genetic diversity. Ann. Rev. Plant Biol. 2008, 59, 313-339. [CrossRef] [PubMed]

33. Perata, P. The rice SUB1A gene: Making adaptation to submergence and post-submergence possible. Plant Cell Environ. 2018, 41, 717-720. [CrossRef]

34. Ueguchi-Tanaka, M.; Ashikari, M.; Nakajima, M.; Itoh, H.; Katoh, E.; Kobayashi, M.; Chow, T.; Hsing, Y.C.; Kitano, H.; Yamaguchi, I.; et al. Gibberellin insensitive dwarf1 encodes a soluble receptor for gibberellin. Nature 2005, 437, 693-698. [CrossRef] [PubMed]

35. Griffiths, J.; Murase, K.; Rieu, I.; Zentella, R.; Zhang, Z.L.; Powers, S.J.; Gong, F.; Phillips, A.L.; Hedden, P.; Sun, T.; et al. Genetic characterization and functional analysis of the GID1 gibberellin receptors in Arabidopsis. Plant Cell 2006, 18, 3399-3414. [CrossRef] 
36. Sun, T.P.; Gubler, F. Molecular mechanism of gibberellin signaling in plants. Annu. Rev. Plant Biol. 2004, 55, 197-223. [CrossRef]

37. Ariizumi, T.; Lawrence, P.K.; Steber, C.M. The role of two F-box proteins, SLEEPY1 and SNEEZY, in Arabidopsis gibberellin signaling. Plant Physiol. 2011, 155, 765-775. [CrossRef]

38. Okada, K.; Ito, T.; Fukazawa, J.; Takahashi, Y. Gibberellin induces an increase in cytosolic $\mathrm{Ca}^{2+}$ via a DELLA-independent signaling pathway. Plant Physiol. 2017, 175, 1536-1542. [CrossRef]

39. Ito, T.; Okada, K.; Fukazawa, J.; Takahashi, Y. DELLA-dependent and -independent gibberellin signaling. Plant Signal Behav. 2018, 13, e1445933. [CrossRef]

40. Ishida, S.; Yuasa, T.; Nakata, M.; Takahashi, Y. A tobacco calcium-dependent protein kinase, CDPK1, regulates the transcription factor REPRESSION OF SHOOT GROWTH in response to gibberellins. Plant Cell 2008, 20, 3273-3288. [CrossRef]

41. Ishida, S.; Fukazawa, J.; Yuasa, T.; Takahashi, Y. Involvement of 14-3-3 signaling protein binding in the functional regulation of the transcriptional activator REPRESSION OF SHOOT GROWTH by gibberellins. Plant Cell 2004, 16, 2641-2651. [CrossRef] [PubMed]

42. Fukazawa, J.; Sakai, T.; Ishida, S.; Yamaguchi, I.; Kamiya, Y.; Takahashi, Y. Repression of shoot growth, a bZIP transcriptional activator, regulates cell elongation by controlling the level of gibberellins. Plant Cell 2000, 12, 901-915. [CrossRef] [PubMed]

43. Fukazawa, J.; Nakata, M.; Ito, T.; Yamaguchi, S.; Takahashi, Y. The transcription factor RSG regulates negative feedback of NtGA20ox1 encoding GA 20-oxidase. Plant J. 2010, 62, 1035-1045. [CrossRef] [PubMed]

44. Ito, T.; Nakata, M.; Fukazawa, J.; Ishida, S.; Takahashi, Y. Phosphorylation-independent binding of 14-3-3 to NtCDPK1 by a new mode. Plant Signal. Behav. 2014, 9, e977721. [CrossRef] [PubMed]

45. Ito, T.; Ishida, S.; Oe, S.; Fukazawa, J.; Takahashi, Y. Autophosphorylation affects substrate-binding affinity of tobacco $\mathrm{Ca}^{2+}$-dependent protein kinase1. Plant Physiol. 2017, 174, 2457-2468. [CrossRef] [PubMed]

46. Morello, L.; Giani, S.; Breviario, D. The Influence of anaerobiosis on membrane-associated rice (O. sativa L.) protein kinase activities. J. Plant Physiol. 1994, 144, 500-504. [CrossRef]

47. Igarashi, D.; Ishida, S.; Fukazawa, J.; Takahashi, Y. 14-3-3 proteins regulate intracellular localization of the bZIP transcriptional activator RSG. Plant Cell 2001, 13, 2483-2497. [CrossRef]

48. Olaetxea, M.; Mora, V.; Bacaicoa, E.; Garnica, M.; Fuentes, M.; Casanova, E.; Zamarreño, A.M.; Iriarte, J.C.; Etayo, D.; Ederra, I.; et al. Abscisic acid regulation of root hydraulic conductivity and aquaporin gene expression is crucial to the plant shoot growth enhancement caused by rhizosphere humic acids. Plant Physiol. 2015, 169, 2587-2596. [CrossRef]

49. Nagel, O.W.; Konings, H.; Lambers, H. Growth-rate, plant development and water relations of the ABA-deficient tomato mutant sitiens. Physiol. Plant. 1994, 92, 102-108. [CrossRef]

50. Thompson, A.J.; Andrews, J.; Mullholland, B.J.; McKee, J.M.T.; Hilton, H.W.; Horridge, J.S.; Farquhar, G.D.; Smeeton, R.C.; Smillie, I.R.A.; Black, C.R.; et al. Overproduction of abscisic acid in tomato increases transpiration efficiency and root hydraulic conductivity and influences leaf expansion. Plant Physiol. 2007, 143, 1905-1917. [CrossRef]

51. Bai, T.; Yin, R.; Li, C.; Ma, F.; Yue, Z.; Shu, H. Comparative analysis of endogenous hormones in leaves and roots of two contrasting Malus species in response to hypoxia stress. J. Plant Growth Regul. 2011, 30, 119-127. [CrossRef]

52. Olivella, C.; Biel, C.; Vendrell, M.; Save', R. Hormonal and physiological responses of Gerbera jamesonii to flooding stress. HortScience 2000, 35, 222-225.

53. Nan, R.; Carman, J.G.; Salisbury, F.B. Water stress, $\mathrm{CO}_{2}$ and photoperiod influence hormone levels in wheat. J. Plant Physiol. 2002, 159, 307-312. [CrossRef]

54. Cowan, I.R.; Troughton, J.H. The relative role of stomata in transpiration and assimilation. Planta 1971, 97, 325-336. [CrossRef]

55. Raschke, K.; Zeevaart, J.A. Abscisic acid content, transpiration, and stomatal conductance as related to leaf age in plants of Xanthium strumarium L. Plant Physiol. 1976, 58, 169-174. [CrossRef]

56. Peng, Y.; Zhou, Z.; Zhang, Z.; Yu, X.; Zhang, X.; Du, K. Molecular and physiological responses in roots of two full-sib poplars uncover mechanisms that contribute to differences in partial submergence tolerance. Sci. Rep. 2018, 8, 12829. [CrossRef]

57. Yordanova, R.Y.; Popova, L.P. Flooding-induced changes in photosynthesis and oxidative status in maize plants. Acta Physiol. Plant 2007, 29, 535-541. [CrossRef] 
58. Du, H.; Chang, Y.; Huang, F.; Xiong, L. GID1 modulates stomatal response and submergence tolerance involving abscisic acid and gibberellic acid signaling in rice. J. Integr. Plant Biol. 2015, 57, 954-968. [CrossRef]

59. Blanke, M.M.; Cooke, D.T. Effects of flooding and drought on stomatal activity, transpiration, photosynthesis, water potential and water channel activity in strawberry stolons and leaves. Plant Growth Regul. 2004, 42, 153-160. [CrossRef]

60. Yetisir, H.; Caliskan, M.E.; Soylu, S.; Sakar, M. Some physiological and growth responses of watermelon [Citrullus lanatus (Thumb.) Matsum. And Nakai] grafted onto Langenaria siceraria to flooding. Environ. Exper. Bot. 2006, 58, 1-8. [CrossRef]

61. Atkinson, C.J.; Harrison-Murray, R.S.; Taylor, J.M. Rapid-flood induced stomatal closure accompanies xylem sap transportation of root-derived acetaldehyde and ethanol in Forsythia. Environ. Exp. Bot. 2008, 64, 196-205. [CrossRef]

62. Ruiz-Sa'nchez, M.C.; Domingo, R.; Morales, D.; Torrecillas, A. Water relations of Fino lemon plants on two rootstocks under flooded conditions. Plant Sci. 1996, 120, 119-125. [CrossRef]

63. Domingo, R.; Pe'rez-Pastor, A.; Ruiz-Sa'nchez, C. Physiological responses of apricot plants grafted on two different rootstocks to flooding conditions. J. Plant Physiol. 2002, 159, 725-732. [CrossRef]

64. Nicolás, E.; Torrecillas, A.; Dell'Amico, J.; Alarcón, J.J. The effect of short-term flooding on the sap flow, gas exchange and hydraulic conductivity of young apricot trees. Trees 2005, 19, 51-57. [CrossRef]

65. Eisenach, C.; Angeli, A.D. Ion transport at the vacuole during stomatal movements. Plant Physiol. 2017, 174, 520-530. [CrossRef] [PubMed]

66. Gonzali, S.; Loreti, E.; Cardarelli, F.; Novi, G.; Parlanti, S.; Pucciariello, C.; Bassolino, L.; Banti, V.; Licausi, F.; Perata, P. Universal stress protein HRU1 mediates ROS homeostasis under anoxia. Nat. Plants 2015, 1, 15151. [CrossRef] [PubMed]

67. Sun, L.; Ma, L.; He, S.; Hao, F. AtrbohD functions downstream of ROP2 and positively regulates waterlogging response in Arabidopsis. Plant Signal. Behav. 2018, 13, e1513300. [CrossRef]

68. Yordanova, R.Y.; Uzunova, A.N.; Popova, L.P. Effects of short-term soil flooding on stomata behavior and leaf gas exchange in barley plants. Biol. Plant. 2005, 49, 317-319. [CrossRef]

69. Zang, J.; Zang, X. Can early wilting of old leaves account for much of the ABA accumulation in flooded pea plants? J. Exp. Bot. 1994, 45, 1335-1342. [CrossRef]

70. Ashraf, M.A. Waterlogging stress in plants: A review. Afr. J Agric. Res. 2012, 7, 1976-1981. [CrossRef]

71. Miao, L.F.; Yang, F.; Han, C.Y.; Pu, Y.J.; Ding, Y.; Zhang, L.J. Sex-specific responses to winter flooding, spring waterlogging and post-flooding recovery in Populus deltoides. Sci. Rep. 2017, 7, 2534. [CrossRef] [PubMed]

72. Vantoai, T.T.; Bolles, C.S. Postanoxic injury in soybean (Glycine max) seedlings. Plant Physiol. 1991, 97, 588-592. [CrossRef]

73. Kalashnikov, Y.E.; Balakhnina, T.I.; Zakrzhevsky, D.A. Effect of soil hypoxia on activation of oxygen and the system of protection from oxidative destruction in roots and leaves of Hordeum vulgare. Russ. J. Plant Physiol. 1994, 41, 583-588.

74. Yan, B.; Da, Q.; Liu, X.; Huang, S.; Wang, Z. Flooding induced membrane damage, lipid oxidation and activated oxygen generation in corn leaves. Plant Soil 1996, 179, 261-268. [CrossRef]

75. Biemelt, S.; Keetman, U.; Mock, H.P.; Grimm, B. Expression and activity of isoenzymes of superoxide dismutase in wheat roots in response to hypoxia and anoxia. Plant Cell Environ. 2000, 23, 135-144. [CrossRef]

76. Kwak, J.M.; Mori, I.C.; Pei, Z.M.; Leonhardt, N.; Torres, M.A.; Dangl, J.L.; Bloom, R.E.; Bodde, S.; Jones, J.D.G.; Schroeder, J.I. NADPH oxidase AtrbohD and AtrbohF genes function in ROS-dependent ABA signaling in Arabidopsis. EMBO J. 2003, 22, 2623-2633. [CrossRef]

77. Coelho, S.M.; Taylor, A.R.; Ryan, K.P.; Sousa-Pinto, I.; Brown, M.T.; Brownlee, C. Spatiotemporal patterning of reactive oxygen production and $\mathrm{Ca}^{2+}$ wave propagation in Fucus rhizoid cells. Plant Cell 2002, 14, 2369-2381. [CrossRef]

78. Fairley-Grenot, K.; Assmann, S.M. Evidence for G-protein regulation of inward $\mathrm{K}^{+}$channel current in guard-cells of fava-bean. Plant Cell 1991, 3, 1037-1044. [CrossRef]

79. Wu, W.H.; Assmann, S.M. A membrane-delimited pathway of $\mathrm{G}$ protein regulation of the guard-cell inward $\mathrm{K}^{+}$channel. Proc. Natl. Acad. Sci. USA 1994, 91, 6310-6314. [CrossRef]

80. Fischer, R.A. Stomatal opening: Role of potassium uptake by guard cells. Science 1968, 160, 784-785. [CrossRef] 
81. Bright, J.; Desikan, R.; Hancock, J.T.; Weir, I.S.; Neill, S.J. ABA-induced NO generation and stomatal closure in Arabidopsis are dependent on $\mathrm{H}_{2} \mathrm{O}_{2}$ synthesis. Plant J. 2006, 45, 113-122. [CrossRef]

82. An, Z.; Jing, W.; Liu, Y.; Zhang, W. Hydrogen peroxide generated by copper amine oxidase is involved in abscisic acid-induced stomatal closure in Vicia faba. J. Exp. Bot. 2008, 59, 815-825. [CrossRef] [PubMed]

83. Song, X.G.; She, X.P.; Yue, M.; Liu, Y.E.; Wang, Y.X.; Zhu, X.; Huang, A.X. Involvement of Copper Amine Oxidase (CuAO)-Dependent Hydrogen Peroxide Synthesis in Ethylene-Induced Stomatal Closure in Vicia faba. Russ. J. Plant Physiol. 2014, 61, 390-396. [CrossRef]

84. Bashar, K.K. Hormone dependent survival mechanisms of plants during post-waterlogging stress. Plant Signal Behav. 2018, 13, e1529522. [CrossRef] [PubMed]

85. Chen, Y.; Huang, R.; Xiao, Y.; Lü, P.; Chen, J.; Wang, X. Extracellular calmodulin-induced stomatal closure is mediated by heterotrimeric $\mathrm{G}$ protein and $\mathrm{H}_{2} \mathrm{O}_{2}$. Plant Physiol. 2004, 136, 4096-4103. [CrossRef] [PubMed]

86. Sasidharan, R.; Voesenek, L.A.C.J. Ethylene-mediated acclimations to flooding stress. Plant Physiol. 2015, 169, 3-12. [CrossRef]

87. Steffens, B.; Sauter, M. Heterotrimeric G protein signaling is required for epidermal cell death in rice. Plant Physiol. 2009, 151, 732-740. [CrossRef] [PubMed]

88. Ge, X.M.; Cai, H.L.; Lei, X.; Zhou, X.; Yue, M.; He, J.M. Heterotrimeric G protein mediates ethylene-induced stomatal closure via hydrogen peroxide synthesis in Arabidopsis. Plant J. 2015, 82, 138-150. [CrossRef]

89. Liu, P.; Sun, F.; Gao, R.; Dong, H. RAP2.6L overexpression delays waterlogging induced premature senescence by increasing stomatal closure more than antioxidant enzyme activity. Plant Mol. Biol. 2012, 79, 609-622. [CrossRef] [PubMed]

90. Hwang, S.-Y.; VanToai, T.T. Abscisic acid induces anaerobiosis tolerance in corn. Plant Physiol. 1991, 97, 593-597. [CrossRef] [PubMed]

91. Gómez-Cadenas, A.; Tadeo, F.R.; Talón, M.; Primo-Millo, E. Leaf abscission induced by ethylene in water-stressed intact seedlings of Cleopatra mandarin requires previous abscisic acid accumulation in roots. Plant Physiol. 1996, 112, 401-408. [CrossRef] [PubMed]

92. Kato-Noguchi, H. Abscisic acid and hypoxic induction of anoxia tolerance in roots of lettuce seedlings. J. Exp. Bot. 2000, 51, 1939-1944. [CrossRef] [PubMed]

93. Ellis, M.H.; Dennis, E.S.; Peacock, W.J. Arabidopsis roots and shoots have different mechanisms for hypoxic stress tolerance. Plant Phyisol. 1999, 119, 57-64. [CrossRef]

94. Dat, J.F.; Capelli, N.; Folzer, H.; Bourgeade, P.; Badot, P.M. Sensing and signaling during plant flooding. Plant Physiol. Biochem. 2004, 42, 273-282. [CrossRef] [PubMed]

95. Hocking, T.J.; Hillman, J.R.; Wilkins, M.B. Movement of abscisic acid in phaseolus vulgaris plants. Nat. New Biol. 1972, 235, 124-125. [CrossRef]

96. Jackson, M.B.; Hall, K.C. Early stomatal closure in waterlogged pea plants is mediated by abscisic acid in the absence of foliar water deficits. Plant Cell Environ. 1987, 10, 121-130. [CrossRef]

97. Rodriguez-Gamir, J.; Ancillo, G.; Gonzalez-Mas, M.C.; Primo-Millo, E.; Iglesias, D.J.; Forner-Giner, M.A. Root signaling and modulation of stomatal closure in flooded citrus seedlings. Plant Physiol. and Biochem. 2011, 49, 636-645. [CrossRef]

(C) 2019 by the authors. Licensee MDPI, Basel, Switzerland. This article is an open access article distributed under the terms and conditions of the Creative Commons Attribution (CC BY) license (http://creativecommons.org/licenses/by/4.0/). 